\title{
Liberating Women: A Cry Transcending Time and Place in William Shakespeare and Begum Rokeya
}

\author{
Sarjana Akter* \\ Lecturer in English, Faculty of Arts and Humanities, University of Chittagong, Chattogram-4331, Bangladesh \\ *Corresponding Author: Sarjana Akter, Lecturer in English, Faculty of Arts and Humanities, University \\ of Chittagong, Chattogram-4331, Bangladesh
}

\begin{abstract}
Ensuring political, economic and cultural liberation of women has been a matter of concern for ages that a lot many writers have emphasized relentlessly. It, therefore, becomes important to dig out how writers across the world have voiced the same urge differently. William Shakespeare and Begum Rokeya, two prominent writers respectively from the West and the East, have communicated this concern from their contemporaneous contexts and perspectives. While Rokeya speaks for the progress of entire Indian woman community straightforwardly, Shakespeare gives turns and twists to words to reach the same utterance. In this paper, it has been interesting to see comparatively how these two writers articulate their liberating thoughts regarding women. To do this, Shakespeare's four plays, by title, Macbeth, The Merchant of Venice, A Midsummer Night's Dream, Twelfth Night and Begum Rokeya's "Streejatir Abanati", "Borka", Padmarag, Sultana's Dream have been brought to scrutinous analysis. The study concludes that liberation of women, in the writings of these two writers, is a demand that can unite the West and the East.
\end{abstract}

Keywords: Woman, Liberation, West, India, Empowerment

\section{INTRODUCTION}

William Shakespeare and Begum Rokeya share spatiotemporal difference, but what leaves a chance to compare them is their willingness, no matter explicit or implicit, to elevate and liberate women from the social, political, economic and cultural confinement. It is important to remember that Shakespeare (1564-1616) writes at a time when women are not even allowed to perform on stage. Therefore, in Shakespeare, there are lots of references to woman empowerment, but mostly implicitly. To voice the necessity to establish a world with equal participation of man and woman is not an easy nut to crack in his time, but Shakespeare often brings his female characters to limelight to promote their empowerment as well as enlightenment. In the Indian subcontinent during $20^{\text {th }}$ century, on the other hand, there appears an other voice, Rokeya Sakhawat Hossain or Begum Rokeya (1880-1932), who strongly feels the need for woman's betterment. Before reflecting on her contributions to contemporary women it is relevant to have a look at her axiomatic belief in "personal is the political" regarding which Selina Hossain explains: "from a lonely sojourner Rokeya now gets resonated in everyone's voice. She is the first to discover the status of women through an axiomatic truth that 'personal is political.' And it's again her contribution to understand the inevitability of participation of both man and woman for collective betterment. Her voice was both timely and timeless" (Hossain 16, self-translation). Individual enlightenment matters most to her only what can ensure collective betterment. To do so, besides preaching through writings, Rokeya has established a girl's school, which is her first step to alleviate darkness from society. A remark on this matter delineates her contributions to the society: "when Rokeya was 29 years old, her husband had died. Before his death, he gave ten thousand taka to Rokeya to establish her school. Though she became upset after the death of her husband, she did not give up her dream. Being strong she established 'Sakhawat Memorial Girls' College' with only five female students on 1st October, 1909, at the residence of the Deputy Magistrate Syed Shah Abdul Malek at Bhagolpur. However, she could not continue her living at Bhagolpur due to the dispute with her in-laws" (Dutta 150, self-translation). Rokeya sacrifices her own happiness, luxury and free time entirely for women's education and their freedom. Moreover, she feels the urgency of releasing women from the so-called patriarchal society where discrimination based on gender is a common matter. Because of the similarities between her activities and 
Shakespeare's vision, it can be bridged that she is born from the ashes of Shakespeare's dream. She is the portrayal imagined by Shakespeare in his writings, Syed proclaims the same for Rokeya in his book Begum Rokeya where he remarks: "such a glorifying figure also digs out the essence of womanhood that Hinduism worships as a concentration of might and that illustrates an instinctive nobility, purity and spontaneity of female character as of nature" (Syed 17, self-translation).That is why, we can claim that while Shakespeare dreams of a new era of women's role, Rokeya, though initiated in a different society, brings to light how women may correspond to a dream from different time and place. To connect these two great thinkers, it becomes important to explore both the conscious and the unconscious aspects of their characters. The real world that they experience and the imaginary world that they fictionalize, both reveal an urge on the parts of the writers to untangle women from the burdens imposed by society. Therefore, this paper argues in favor of how a dream of a free world where men and women equally participate is not a spatiotemporal issue, instead a global resonance, through the analysis of Shakespeare and Rokeya. To conduct the study, Freudian psychoanalysis is a big help to whom human psychology is divisible and analyzable. To establish the statement promulgated above, the study has based its analysis on William Shakespeare's four plays: Macbeth, The Merchant of Venice, A Midsummer Night's Dream, Twelfth Night, and Begum Rokeya's four literary pieces including essay and fiction: "Streejatir Abanati" (Essay), "Borka" (Essay), Padmarag, Sultana's Dream. References to "Streejatir Abanati" (Essay) and "Borka" (Essay) better illustrate her beliefs and visions that the study seeks help to at times. The study, therefore, has attempted to prove that in spite of belonging to two different eras and two different geographies, Shakespeare and Rokeya voice for woman's liberation from male domination that requires courage at their times and that eventually unites them.

\section{FEMINISM}

To establish women as equal to men is not a recent phenomenon, it has passed a long history of struggle that includes both political and literary activities. In support of this assertion, in Peter Barry's Beginning Theory it has been claimed, feminism is "an old tradition of thought and action," and it mainly addresses "the problem of women's inequality in society" (Barry 121). From the beginning of civilization, the depravity that the women are going through has been a matter of thought for a good number of progressive intellectuals. And the expression of their thoughts has been reflected in their writings regarding which in the aforementioned text it has been mentioned: "this movement was, in important ways, literary from the start, in the sense that it realized the significance of the images of women promulgated by literature" (Barry 121). The literary movement that the writers inaugurated does not remain confined to any particular time and place. Instead the conscience of every thoughtful human being has felt the necessity to improve the condition of the woman in order to build a better world. The voice, therefore, gets stronger when the contemporary time sees disparity between genders. Regarding the courage few women showed during the time of Shakespeare to act direct on stage an article has been written in The Guardian where the author mentions: "Shakespeare's female roles were played by boys or young men until 1660, but new research by the British Library has uncovered details of the careers of the few, ground-breaking women who began to take on major Shakespearean characters in the face of the prejudice of their times" (Thorpe). This quote essentially proves that it is not allowed for women to act on stage and connotatively it brings forth their imprisoned state. The same happens to women in Rokeya's time about which it has been reported in "Begum Rokeya: The pioneer feminist of Bangladesh": "During her time, the women of whole Indian subcontinent were suffering from decadence, ignorance, and frustration. Because, women were restricted within four walls, and had to maintain purdah even in front of women who are not their relatives" (Noyon). The experiences that Shakespeare and Rokeya underwent during their lifetime inspires them to stand by a deprived and underprivileged humanity. This same realization, therefore, unites William Shakespeare and Begum Rokeya who voice a need to reconsider the condition of the woman and to redistribute their roles in the society.

\section{SigMUND FREUD'S UNCONSCIOUS}

The western era of William Shakespeare fails to place the woman side by side with the man and the same happens with Begum Rokeya who understands the misery of the contemporary woman in Indian subcontinent, but fails to make the society understand. Therefore, representation of their time through writings cannot unconditionally follow a linear way, instead they even are bound to explore woman unconscious to bring out in-depth desires and dreams. To shed light on this aspect, the psychoanalysis 
of Sigmund Freud is a help according to whose theory: "a three-part, rather than a two-part, model of the psyche, dividing it into the ego, the super-ego, and the $i d$," corresponds to three personality levels namely "the consciousness, the conscience and the unconscious"(Barry 97).The consciousness is aware part of human psychology that the name itself suggests, the conscience is related to the function deciding between right and wrong, and the unconscious, in Freudian psychoanalysis is of significance as it "is the part of the mind beyond consciousness which nevertheless has a strong influence upon our actions"(Barry 96). Therefore, the unconscious is where someone's inner thoughts and dreams are stored and that may make a way out in the real world in different ways. In Shakespeare and Rokeya, reflection of woman's unconscious can be observed which declare the strong will-power of woman's world.

\section{FEMINISM IN SHAKESPEARE}

Anthony Davis mentions: "Charles Marowitz, whose productions of Hamlet and Taming of the Shrew aroused such immense controversy, has maintained that the life force of a Shakespearean play is not embedded in the text, but results from an interaction between the imaginative mind and the text" (Nizam 114). This quote makes it clear that Shakespeare does not reside in an imaginary world, his writings are inspired by reality and reality is what gets fictionalized in him. Therefore, what Shakespeare claims regarding women describes the condition of his contemporary counterparts and recommends ways for advancement.

Shakespeare's age has witnessed the tremendous victory of colonization and such political practice has a direct impact on the treatment to women in his days. During $16^{\text {th }}$ and $17^{\text {th }}$ century, British rule was dominating the world through its colonies. However, it is not unusual to witness how women also prevail as empowered rulers in British empire during that time. When Shakespeare has been writing his plays, he has got the experience of the era of Queen Elizabeth. Thereby, politics is not only in men's mind or rationale but also in woman's veins, since colonizers are born from colonizers' wombs. In other word, women have been involved in politics. From this perspective, Britain can be considered as a macrostructure to British people, a British family is a microcosm with the opulence of its politics. However, it is not impossible that Shakespeare's insight dreams of a world where one day patriarchy will bury its head upside down, and colonizers will be colonized by their subalterns. His character Lady Macbeth spells out his horrified mind. She is so desperate to kill the king and becomes unable to control her mind on which she says: "I laid their daggers ready; /He could not miss "em. Had he not resembled/ My father as he slept, I had done't." (II.ii.864). Nizam supports this in her "Politics of Gender and Power: Shakespeare's Lady Macbeth in Polanski's Film Adaptation" where she expresses: "His (Macbeth) lust for absolute power becomes so intense that he completely excludes his wife from political decisions as he has complete knowledge about her persuasive power" (Nizam 120). However, it will be a partial judgment if we look for political affairs only in its darker places, because Shakespeare presents women with good intentions relating them with political affairs. In The Merchant of Venice, Portia shows her logical participation to save Bassanio by solving a nearimpossible case, even by complying with all conditions given by Shylock. In act IV scene i, she says: "Therefore prepare thee to cut off the flesh. / Shed thou no blood, nor cut thou less nor more" (IV.i.410). If Shakespeare would against be women's liberation, he would not appoint even his fictional female charactersto conduct such crucial political affairs. Their such participation in state's bureaucracy reveals Shakespeare's inner mind to engage women in every sector of the society that gets a vivid exemplification in Macbeth or in The Merchant of Venice.

Secondly, Shakespeare visualizes women beyond their traditional role. Traditional practices could only visualize women from a biological perspective. They are supposed to be wives and mothers identically. From the previous illustration of women, it can be observed that women such as Lady Macbeth or Portia has transcended the boundary of traditional submissiveness. None of them play the role of a woman (being a sexual partner or a wife with repressed desire), rather they demonstrate how women have intelligence to contribute, desire to fulfill and courage to fight, just like men do. As we have already talked about Portia, her logical reasoning to unfold the knot is praiseworthy to its audience. She herself assures Shylock in act IV scene i: "Thyself shalt see the act: / For, as thou urgest justice, be assured/ Thou shalt have justice, more than thou desirest." (IV.i.410).Even Shakespeare shows how a girl can take decision of her own marriage eloping from home, ignoring the Draconian law of Athens and breaking the cruel law of patriarchy. Hermia, in A Midsummer Night's Dream, elopes with Lysander, instead of obeying her father, Egeus, and embracing the death in either way. 
Hermia shows courage in front of Duke Theseus to tell that she will never surrender herself to someone whom her soul is not ready to accept. She asserts in act I scene i: "So will I grow, so live, so die, my lord, / Ere I will my virgin patent up/ Unto his lordship, whose unwished yoke/ My soul consents not to give sovereignty" (I.i.280). She establishes an instance of courage, which Lady Macbeth does as well, but in a valiant manner. The latter lady does every possible thing to accomplish the conspiracy of killing Duncan. In act II scene ii, she talks to herself: "That which hath made them drunk hath made me bold; / What hath quenched them hath given me fire" (II.ii.864). She also confesses to her deed saying: "Do mock their charge with snores: I have drugg'd their possets, / That death and nature do contend about them/ Whether they live or die" (II.ii.864). Besides, the scene of Macbeth's entry into his house becomes crucial for the interpretation of how power changes its source from a man to a woman (Nizam 116). So, there is no room for being skeptical that Shakespeare's women characters are represented almost equal to men, and who have simultaneous roles of being female counterparts in the society.

Finally, culture not only determines our role in society, whether to be feminine or masculine, but molds both extrinsic and intrinsic ways of behavior. In the plays of Shakespeare, we find a combination of his dream and social experience. Though he tries to sketch women in a different frame, he cannot ignore the social practice. However, his plays extend the shadow of his mental urge to drag women out of cocoon so that they can strive, choose, decide, and in a word, they can exist as an individual. Shakespeare empathizes women through Portia's voice in act I scene ii: "But this reasoning is not in the fashion to/ choose me a husband: $\mathrm{O}$ me, the word 'choose'! I may neither choose who I would, nor refuse who I dislike; so is the will of a living daughter curb'd by the will of a dead father. /Is it not hard, Nerissa, that I cannot choose one, nor refuse none?" (I.ii.390). Again, in Twelfth Night, Viola needs to hide herself behind the mask of Cesario. As a woman, she cannot exist in the open air because of social prejudices. She asks the captain in act I scene ii: "Conceal me what I am, and be my aid/ For such disguise as haply shall become/ The form of my intent" (I.ii.642). Moreover, by hiding her true identity, Viola proves her least difference from Sebastian, who is free to breath in the air with his own identity, unlike Viola. Even Sebastian, being her brother, could not recognize her at first sight. Sebastian asks her in act V scene i: "Do I stand there? I never had a brother;/ Nor can there be that deity in my nature, / Of here and everywhere. I had a sister, / Whom the blind waves and surges have devour'd. / Of charity, what kin are you to me? / what countryman? what name? what parentage?" (V.i.667). Nizam critically investigates how the playwright's thought has gone beyond the boundary of gender. She remarks: "She (Lady Macbeth) feels invigorated with the energy achieved by unsexing herself which helps to suppress everything feminine within her" (Nizam 116). Since Shakespeare experiences the condition of women in his society, he shows the world that their potential should be treated equally. To balance between obligation and desire, to untie the rigid rules of society, women needs to pretend as men, as Viola and Portia have done individually at Shakespeare's time. In addition, as women are not allowed to perform on stage, male performers adopt the attire of women. However, such camouflage does not bring any good to the society, rather complicates the social functioning. Still, the playwright produces such characters, and it indicates how intensely he wants that women should come out of their veil and declare their existence to the world. Nizam, in this regard, tries to discover playwright's mind as he points out: "Her (Lady Macbeth) existence is defined by her wit, strength of nerves, persuasive power and amazing intellectuality which has no use in the domestic life where she is forced to live devoid of any control and authority" (Nizam 120).

Though we can look at Shakespeare's works from both feministic and anti-feministic point of view, there are several characters created in his plays which cannot be denied as anti-feministic. Novy supports this concept in his "Demythologizing Shakespeare" by explaining the role of Kate in The Taming of the Shrew where he shows Kate "as the real victor" (Novy 18). Though it seems Kate is tamed at the end, she actually has learned how to control her husband, Petruchio. Shakespeare elaborates women's position considering their political, biological and cultural contexts. To be brief, he sketches an abstract picture to be colored by individual insights.

\section{FEMINISM IN ROKEYA}

Rokeya exists in a world where the society is not ready to accept the woman's contribution to the development of civilization. She has to fight against the opposite power in society as well to establish women's right. For this, Mannan terms Rokeya as a mighty warrioron which he mentions: "Against 
shared immobility among generations for eons and consequent backwardness, she composed the matchless musing. Never did she stop her championing fight against an evil majority of reactionaries. No matter the rivalry was man or women, she paraded unstoppably in the battlefield that led to emancipation of women subjugating a fatigued socio-culturalization of civilization" (Mannan 93, selftranslation).Rokeya herself declares in "Streejatir Abanati", "I know, it's daunting to make the first call. Nor am I unaware of the subsequent coercion on the part of the society afterwards - in consequence, Indian Muslims might declare punitive death sentence for us and Hindus would not lag behind in preparing fiery deathbed or even extremely icy one (nor our sisters are willing enough to wake from this slumber up). But it's time to raise voice for social welfare. To reach the end, certainly a thorny way has to be stamped on" (20, self-translation). Therefore, Rokeya acts like a visionary revolutionary to alleviate the social obstacles in the way of women's righteous development. It is important to remember that in Rokeya's definition of liberty, there is no scope for culturaldisorientation and this is why she upholds women's right, never disobeying the ideals of Islam. She tries to explain every right keeping herself as a Muslim woman. In her essay "Borka", she describes: "Many times I have come across the complaint that suggests veil as the foremost obstacle on the way of our progress. Even our highly educated sisters often summon us to denounce veil. Doesn't this call, therefore, raise another question: what does progress denote? Does progress inhabit only the world bereft of veil? And if it would be the fact, wouldn't it be logical to conclude that women from fishing, cobbling or minor communities are more enlightened than us" (41, self-translation). Therefore, it can be concluded that her fight is against the social prejudices and to eliminate this, she gives words to her beliefs. Characters from her fictions triumphantly show her vigor to protest any unruly treatment to women and to establish all kinds of rights of theirs.

Similar as Shakespeare's Lady Macbeth, in Rokeya, there is story, titled Sultana's Dream, of woman empowerment. There the Queen rules the land with the advice from ladies expert at the art of war, science and peace. With the help of woman engaged in a number of important positions she proves it worthless to believe that women are weaker than their male counterparts. The strength of woman needs not account for only physical superiority, but it can dwell in intellectual power regarding which she says: "if you cannot save your country for lack of physical strength...try to do so by brain power" (482). Woman does not lag behind in the practice of power, if they are given chance and that is what makes Rokeya a prominent figure.

Again, in Sultana's Dream, a Lady Principal who invents the technology of collecting sun-heat, takes the responsibility of facing an invading enemy while all the man take shelter after being defeated in the battlefield (482). The Lady Principal innovatively exposes the enemies to scorching sun-heat that they fail to forbear: "the heat and light were too much for them to bear. They all ran away panicstricken, not knowing in their bewilderment how to counteract that scorching heat. When they fled away leaving their guns and other ammunitions of war, they were burnt down by means of the same sun-heat" (483). Therefore, in Rokeya's belief, women are capable of handling such crises that demand much planning and intelligence on warfare. Here Shakespeare's portrayal of Portia gets a resemblance as she also shows the capability of dismantling a critical situation.

In most cases, the era that Begum Rokeya is writing in, does not permit the woman to unveil their true self. They are compelled to play the roles the society has provided them with. In doing so, the woman eventually kills their spontaneous self. In spite of being prohibited in real-life society, the literary practice of Rokeya brings out the innermost self of the woman which gets a reflection in her novella Padmarag where the protagonist Siddika gets a chance to lead an economically certain married life, but she refuses as her would-be-in-laws once are more attracted to her wealth instead of herself (259378). The second chance of being married to the same person with the first-time proposal demands her determination to be refused on which she reflects: "I want to show the society that marriage is not the ultimate goal of female life. And leading a family life does not necessarily make it a success. This sacrifice of mine, I believe, will contribute to female betterment in future" (365, self-translation). Taking a such strong decision is not usual in that time as women are considered to be subjugated to their male partners. How Siddika upholds her sense of pride instead of being immersed in the traditional definition of female life and acknowledging the pitfalls of single-woman life in future, is the dream that Rokeya dreams of. Such example makes further appearance through another important character named Tarini in Padmarag who fights all the odds of the society and oppositions from her own family to establish Tarini Bhaban (268). It is mentionable here that Tarini is a widow who 
despite knowing the economic and social helplessness awaiting her, dedicates her wealth for social welfare. Tarini Bhaban mainly works for educating girls, sheltering the unsheltered, treating the un curableas well as the helpless, and empowering the tortured women and widows of contemporary society (268). Such willpower of Tarini that drives her to listen to her self is an example of woman's liberation: "her relatives got dissatisfied with her deeds. They turned irritated and began to think that Tarini had wasted more than lakh taka unnecessarily. Not only they regretted Tarini's decision, they lampooned her equally" (268, self-translation).

Sultana's Dream is a science fiction where a girl named Sultana goes to a different world in dream. In her dream-world, the woman reigns over the man and the entire society is properly organized that wholly tries to establish the truth that women are better rulers. The beliefs that the land is founded on get expression in the words of the Queen of Dreamland: "we do not covet other people's land, we do not fight for piece of diamond though it may be a thousand-fold brighter that the Koh-i-Noor, nor do we grudge a ruler his Peacock Throne. We dive deep into the ocean of knowledge and try to find out the precious gems, which nature has kept in store for us. We enjoy nature's gifts as much as we can" (485). Sultana's dream is a reflection of her thoughts regarding the society she lives in. How woman can prove themselves as better rules, how woman excels at every art of knowledge and technology and how woman can win the battlefield, Sultana's unconscious reserves a good number of techniques and strategies regarding this. However, as she is "a purdahnishin woman" and "not accustomed to walking about unveiled" she cannot speak out her dreams. Her unconscious speaks through the voice of dream which thinks of a "Lady land free from sin and harm. Virtue herself reigns here" (477). Rokeya who sees the plight of woman in the real world, creates an imaginary land where women are liberated from every boundary. In this analysis, Freudian psychoanalysis plays a role as in his terms, the unconscious is the reservoir of human's unexpressed self. While the conscious acts according to rules and norms of the society, the unconscious is free from these obstacles and it can voice the hidden self of a being.

\section{Comparitive ANALYSIS BETWEen SHAKESPEARE AND ROKEYA}

William Shakespeare and Begum Rokeya share different geographies, different culture and different times. However, in both's writings, there is a wide similarity that works for woman's emancipation of selfhood. Despite having differences, Shakespeare's dream can be compared to Rokeya's Sultana's Dream, where a new world comes to light submerging the idea of 'dual domination' (Islam 316), where the subaltern changes the power relation. As stated in the previous section, Shakespeare is either dreamt of or is scared of the alteration of powerful position from personal to political relation. In Sultana's dream, zenana has been transformed into murdana, and Shakespeare may have thought the same, leading a life in Elizabethan reign. The dreams are different as well, for Rokeya, unlike Shakespeare, she awakes Sultana in herself and tries to implement her dream into real life. She has to suffer, struggle and also strive to establish women's right in society. She does not allow her dream to be turned into ashes, rather she sheds light on her wishes, like a gyre as it starts every time from where it ends. The grief of her husband's death, misbehaviors of family members or ignorance of society could not come in her way of establishing school. She thinks of the amelioration of society as a whole and works as a humanist, more than a feminist. Both Shakespeare and Rokeya believe that women have lack of opportunity to do something noteworthy in society. As an individual, they could not decide, choose or direct their wish, rather, they are parasites to live on the male members of their family, who rule and exploit their potential. Lady Macbeth who unfairly tries to achieve power represents the dark spirit of womanhood, but she, at the same time, stands as a symbol of empowerment. No matter how much unfair her means are, she retains the capacity to stand the strategy of any existing male counterpart. In Rokeya, such political activism of women has been portrayed by the Queen from Ladyland. She proves herself to be a successful ruler with her timely and wise decision. The Queen, therefore, represents a positive spirit who can equally contribute to the advancement of the society. In The Merchant of Venice, therefore, what Portia shows about herself through her intelligent advocacy gets a similar reflection in Lady Principal's way of preventing an approaching army in Rokeya's Sultana's Dream. Portia and Lady Principal employ their knowledge and instantaneous decision-making to save human life. Therefore, it brings both Shakespeare's and Rokeya's belief to light how women can prove themselves to be better decision-makers. In the next phase, it is important to take into account Hermia, Shakespearean character, who prefers her decision to her father's one. In Rokeya, such a figure reveals herself through the character Siddika who 
disobeys the societal norms regarding marriage and listens to herself for the sake of honor. It does not matter whether Hermia and Siddika have taken the right or wrong decisions; instead it matters, how through listening to their selves, they become the proponents of individualism. Unless the woman gets rid of dependency on their male counterparts, they cannot liberate themselves unconditionally. In the next discussion, it is relevant to bring Viola and Sultana to light. Shakespeare's Viola pretends to be Cesario to survive in the society. However, pretension does not come single handed, rather it requires all the roles that a boy in that time is supposed to play. Therefore, it becomes clear that Viola is capable of performing all the male roles to survive as Cesario. In spite of being able, she cannot expose herself to the society as she is a woman. Cesario, therefore, symbolizes her unconscious where all her abilities and dream reside, but her conscious self fails to unveil those due to social restrictions. The same happens to Sultana who dreams of a world where women can implement their intelligence, but her real world is not ready to accept it. Therefore, her dream world becomes the symbol of her unconscious which does not need to follow social restrictions. Viola and Sultana are reflections of Shakespearean and Rokeyan utopia that are formed on the basis of woman's empowerment.

\section{CONCLuSion}

How William Shakespeare and Begum Rokeya demonstrate their ideas and thoughts about women through their writings is canonical as their portrayals display woman's capability, potential and intelligence. Only by engaging such a large part of humanity in the development of civilization can build an enlightened world. This single urge that equalizes man and woman eventually eliminates boundaries of time and place. This has particularly happened to these writers who, in their writing, formulate a world of equality, participation and development. Although the voice of William Shakespeare is not always loud and explicit enough to shake the entire world to wake up to a new world of equality, Begum Rokeya is much straightforward and uncompromising in this regard. As Shakespeare inhabits a world of ancient ideas and beliefs as well as patriarchy, it is not possible for him to revolutionize his time all of a sudden-and this is why his writings entail a secret world of woman's freedom, power and intellect. In contrast, Begum Rokeya, being originated from a land of woman's miseries in terms of education, life and thought, has proclaimed the necessity to build a free world where the contributions of woman go together with man. Shakespeare's female characters require deep analysis to make themselves understood, but Rokeya's characters stand bold and clear regarding their rights. However, in spite of having much differences the way Shakespeare and Rokeya give voice to their thoughts, both of the writers have made contributions to the betterment of an unattended community, that is, the woman. And this is where the writers transcend their own time and origin and draw a line of resemblance.

\section{REFERENCES}

[1] Hossain, Selina. "Bangalir Jagorone Rokeyar Attoshokti." Ushaloke, vol. Naba Parjaay, no.7, 2013, pp. 916.

[2] Dutta, Nibedita Chakraborti. "Sobar Upore Sottyo Je Manush.” Ushaloke, vol. Naba Parjay, no.7, 2013, pp. 148-153.

[3] Syed, Abdul Mannan. Begum Rokeya. Dhaka, Abosar, 2011, pp. 1-120.

[4] Barry, Peter. "Feminist Criticism." Beginning Theory. UK, Manchester UP, 1995, pp. 121-138.

[5] ---. "Psychoanalytic Criticism." Beginning Theory. UK, Manchester UP, 1995, pp. 96-120.

[6] Thorpe, Vanessa. "Secret Lives of women who broke taboo to act in Shakespeare." The Guardian, Online ed., 10 April 2016, www.theguardian.com/culture/2016/apr/10/secret-lives-of-women-shakespeare. Accessed 28 June 2019, 12:25 PM.

[7] Noyon, Toufik Ahmed. "Begum Rokeya: The pioneer feminist of Bangladesh." The Daily Observer, Online ed., 9 February 2017,www.observerbd.com/details.php?id=57669\&fb_comment_id=12566864077 46350_ 1257494377665553. Accessed 28 June 2019, 12:40 PM.

[8] Nizam, Hamalna. "Politics of Gender and Power: Shakespeare's Lady Macbeth in Polanski's Film Adaptation." Crossings, vol.6, 2015, pp. 112-122.

[9] Novy, Marianne. "Demythologizing Shakespeare." Women's Studies, vol.9, no.1, 1981, pp.17-27.

[10] Shakespeare, William. A Midsummer Night's Dream. The Complete Works of William Shakespeare, London, Wordsworth Editions Limited, 2007, pp. 279-301.

[11] ---. Macbeth. The Complete Works of William Shakespeare, London, Words worth Editions Limited, 2007, pp. 858-884. 
[12] ---. The Merchant of Venice. The Complete Works of William Shakespeare, London, Wordsworth Editions Limited, 2007, pp. 388-415.

[13] ---. Twelfth Night. The Complete Works of William Shakespeare, London, Wordsworth Editions Limited, 2007, pp. 641-669.

[14] Mannan, Sarkar Abdul. "Rokeya Sakhawat Hossain: Narijagoroner Shaswata Shilpi." Ushaloke, vol. Naba Parjaay, no.7, 2013, pp. 93-111.

[15] Hossain, Rokeya Sakhawat. "Borka." Rokeya Rachanabali. Edited by Abdul Quadir, Dhaka, Bangla Academy, 2018, pp. 41-46.

[16] ---.Padmarag. Rokeya Rachanabali. Edited by Abdul Quadir, Dhaka, Bangla Academy,2018, pp. 259-378

[17] ---. "Streejatir Abanati." Rokeya Rachanabali. Edited by Abdul Quadir, Dhaka, Bangla Academy, 2018, pp. 11-22.

[18] ---.Sultana's Dream. Rokeya Rachanabali. Edited by Abdul Quadir, Dhaka, Bangla Academy, 2018, pp. 475-488.

[19] Islam, Syed Manzoorul. "Subaltern's World View: A reading of Sultana's Dream." Ushaloke, vol. Naba Parjaay, no.7, 2013, pp. 313-318.

\section{AUTHOR'S BIOGRAPHY}

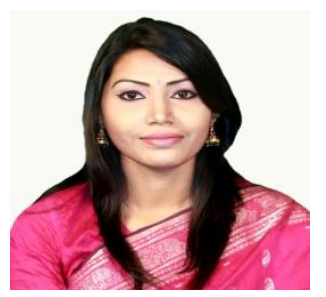

Sarjana Akter is currently serving as a Lecturer in English, Faculty of Arts \& Humanities, University of Chittagong, Chattogram-4331, Bangladesh. She completed her Honors in English from University of Dhaka, Bangladesh in 2012 and Masters in English Literature from the same institution in 2013. She loves to work on Feminist Literature and South Asian Literature in English.

Citation: Sarjana Akter. Liberating Women: A Cry Transcending Time and Place in William Shakespeare and Begum Rokeya. "International Journal on Studies in English Language and Literature (IJSELL), vol 7, no. 12, 2019, pp. 55-62. doi: http://dx.doi.org/10.20431/2347-3134.0712004.

Copyright: (c) 2019 Authors. This is an open-access article distributed under the terms of the Creative Commons Attribution License, which permits unrestricted use, distribution, and reproduction in any medium, provided the original author and source are credited. 